\title{
KINERJA DOSEN: KONTRIBUSINYA TERHADAP AKREDITASI PERGURUAN TINGGI
}

\author{
Wahyudi \\ Universitas Pamulang, Banten \\ dosen00716@unpam.ac.id
}

Submitted: 02 ${ }^{\text {nd }}$ April 2020/ Edited: $25^{\text {th }}$ August 2020/ Issued: 01 ${ }^{\text {st }}$ October 2020 Cited on: Wahyudi, W. (2020). KINERJA DOSEN: KONTRIBUSINYA TERHADAP AKREDITASI PERGURUAN TINGGI. SCIENTIFIC JOURNAL OF REFLECTION: Economic, Accounting, Management and Business, 3(4), 401-410.

DOI: $10.5281 /$ zenodo.4427642

https://doi.org/10.5281/zenodo.4427642

\begin{abstract}
Accreditation is evidence of the performance of higher education, which explains that the university is aware of the quality of education. Therefore, encouraging the improvement of lecturer performance is a necessity. Lecturer performance is one of the absolute instruments of accreditation, which cannot be ignored. Its existence contributes directly to the realization of the Tri Dharma and the performance of the institution, so that all interests are accommodated (both students and universities). This study aims to reveal the performance of Pamulang university lecturers, and review the extent of their contribution to the accreditation of institutions (study programs and universities). For this reason, a qualitative approach is used, as an effort to uncover the phenomenon as it really is. The type of data is secondary, which is obtained from the Dikti database, Unpam Staffing, Campus Research Institute, and the Sinta Dikti page. The results of the study revealed that the performance of Pamulang University lecturers was low, meaning that the performance achievements of education, research, service, and support had not met the expectations of accreditation. With a large number of lecturers, Tri Dharma's performance achievements are still low, for example, there are very few evidences of performance in the form of books, minimally accredited national journals, very few reputable international journals, and the number of awards/recognition at the national or international level does not yet exist.
\end{abstract}

Keywords: Accreditation, Educational and Teaching Performance, Research, Services

\section{PENDAHULUAN}

Hal yang diharapkan dari seorang dosen adalah kinerja dalam Tri Dharma, apa artinya? Seorang dosen melakukan tugasnya dengan benar. Di mana seluruh komponen kewajiban ditunaikan sebagaimana tuntutan, dan dampak dari hal itu adalah keseimbangan antara ilmu pengetahuan dan kontribusi bagi khalayak banyak. Hal ini pun menjadi bukti, bahwa label dosen yang melekat tidak hanya sekedar teori, akan 
tetapi penegas nyata bahwa berilmu itu dapat memberikan perubahan, baik mencerdaskan maupun menyejahterakan (Aisyah, et, al., 2019).

Dosen adalah profesi yang mengharuskan pelakunya memenuhi tiga dimensi, yakni kecerdasan intelektual, kecerdasan emosional, dan kecerdasan spiritual (Abramovskikh, et, al., 2019). Ketiga hal tersebut penting bagi terwujudnya pelaksanaan Tri Dharma secara baik dan benar, atau disebut juga kohesif. Artinya, seorang dosen menjadikan pelaksanaan Tri Dharma tidak hanya sekedar kewajiban, namun sebuah jalan hidup yang harus ditempuh. Hazriyanto, et, al. (2019), menyatakan kinerja dosen terlihat secara kasat mata, jika dalam pendidikan dapat dibuktikan dengan ijazah, dalam pengajaran dapat dibuktikan dengan kehadiran, dalam penelitian dapat dibuktikan dengan jurnal, dan dalam pengabdian dapat dilihat dari laporannya. Namun, kesemua itu, hanya akan terwujud jika seorang dosen benar-benar memilih menyadarinya. Terlepas dari hal apapun, urgensi dari kinerja dosen adalah dampak yang ditimbulkannya, baik bagi institusi maupun pihak-pihak lain.

Bagi institusi kinerja dosen secara keseluruhan sangat mempengaruhi terhadap banyak bidang, tidak terkecuali akreditasi dan mutu penyelenggaraan pendidikan. Bahkan, dalam konteks yang luas, dapat menimbulkan citra positif di tengah-tengah masyarakat. Misalnya, baiknya kinerja pengajaran dosen dapat mempengaruhi emosi peserta didik, secara tidak langsung para mahasiswa akan menjadi media promosi yang baik bagi institusi pendidikan. Oleh karenanya Suherman, dkk., (2019) dan Yulianti (2020) menyatakan, syarat mutlak seseorang menjadi seorang dosen adalah memiliki ilmu pengetahuan yang matang dan berjiwa pendidik (disebut juga dengan kompeten).

Lebih lanjut, kinerja dosen dalam bidang penelitian secara eksplisit berkontribusi besar terhadap reputasi perguruan tinggi, yakni berupa akreditasi. Hal tersebut dapat menaikkan popularitas lembaga pendidikan secara luas. Selain itu, kinerja penelitian dapat membawa perguruan tinggi pada sebuah pengakuan oleh lembaga nasional dan internasional, sehingga dapat memperkuat posisi perguruan tinggi di dunia pendidikan. Bahkan dampak hal tersebut dapat menciptakan kepercayaan masyarakat akan kualitas atau mutu pendidikan yang diselenggarakan. Dalam sebuah riset dijelaskan, kinerja dosen yang paling dilihat adalah karya dari hasil penelitian, di mana bukti tersebut dapat dilihat pada jurnal-jurnal nasional ataupun internasional bereputasi, yang memperkuat 
citra perguruan tinggi dan dosen yang bersangkutan (Sofyani \& Nazaruddin, 2019; Putri, et, al., 2019).

Hal lain yang penting dari kinerja dosen adalah pelaksanaan pengabdian kepada masyarakat. Kegiatan tersebut secara sistematis memiliki urutan yang final, di mana seorang dosen diminta memberikan bukti atas keilmuan yang dimiliki, yakni dengan berkiprah dan melakukan tindakan nyata yang dapat mendorong perbaikan di tengahtengah kehidupan masyarakat. Misalnya dengan memberikan pelatihan beragam kegiatan bernilai ekonomi, melakukan pembinaan usaha atau bisnis, menjadi mentor bagi sebuah usaha atau kegiatan, dan menjadi pelopor dalam kegiatan kemanusiaan lainnya, seperti penggerak kegiatan sosial, keagamaan, bantuan hukum, dan lain sebagainya.

Salbiah, et al (2019) menjelaskan, kinerja memiliki makna yang luas, bahkan berarti dampak. Oleh karena itu, setiap organisasi menghendaki para anggotanya berkinerja, karena berarti tujuan organisasi tercapai. Selain itu, kinerja memiliki arti tersendiri bagi setiap individu pekerja. Mereka yang berkinerja merasakan kebanggaan diri, bahwa ia memiliki nilai yang layak untuk diapresiasi.

Pachler, et al (2019), kinerja bagi seorang pengajar berarti luas, namun yang paling nyata adalah tercapainya proses belajar yang bermutu. Para siswa mendapatkan pengetahuan yang cukup, bertindak etis, dan berprestasi. Inilah alasan utama, Menagpa setiap pendidik secara sukarela berupaya keras untuk berkinerja. Di sisi lain, dampak ini menjadi nilai citra bagi institusi. Di mana masyarakat melihat kualitas lembaga pendidikan pada diri anak-anak mereka, dan menempatkannya pada persepsi yang tinggi, yakni popularitas (Thach, et al., 2019).

\section{LANDASAN TEORI}

Memahami dosen, terletak pada dua hal. Pertama, dosen sebagai profesi. Kedua, dosen sebagai pribadi. Secara teoritis, dosen dari sudut pandang profesi telah dijelaskan dalam UU no.20 tahun 2003 dan secara spesifik dijabarkan pada Permen No. 26 tahun 2015. Di mana dosen adalah:

1. Dosen adalah pendidik. Artinya, dari sudut pandang profesi dosen diwajibkan memiliki kemahiran di dalam menyampaikan ilmu, membimbing, melatih, memotivasi, dan membina peserta didik. Dalam konteks ini, dosen dituntut 
jiwanya, kesadarannya, motivasinya, dan hasratnya untuk mendedikasikan diri mencerdaskan peserta didik. Maka, dengan adanya batasan ini, seorang pendidik harus memposisikan diri sebagai teladan. Orang yang layak dicontoh pemikirannya, sikapnya, dan perilakunya. Namun, hal yang perlu dipahami, penejelasani ini tidak bersifat bawaan, apa artinya? Artinya, ketika seseorang memutuskan menjadi seorang dosen, maka ia berkewajiban mengarahkan dirinya untuk menjadi teladan, dalam setiap kedidupannya adalah refleksi dari keteladanan, sehingga terbentuk kepribadian teladan.

2. Dosen adalah orang yang profesional. Kata profesional bermakna ahli, terampil, dan mampu. Sederhananya, seorang dosen wajib:
a. Bisa mendidik
b. Bisa menyampaikan ilmu
c. Bisa membimbing
d. Bisa melatih
e. Bisa mengembangkan

Kesemua di atas adalah komponen utama dalam tahap aktivitas sebagai seorang dosen.

3. Dosen adalah seroang ilmuwan. Sedangkan ilmuwan, berarti seorang dosen mendedikasikan dirinya untuk terus mengembangkan keilmuan (melakukan penelitian dan pengabdian) sehingga dapat memberikan manfaat kepada banyak pihak (baik bersifat teoritis maupun empiris). Dalam konteks ini, sesungguhnya peran dosen lebih ke arah eksternal, yakni;

a. Dituntut untuk mengembangkan suatu metode mengajar dan atau ilmu pengetahuan, sehingga dapat memudahkan peserta didik dan atau masyarakat dalam memahami suatu ilmu.

b. Dituntut untuk menciptakan karya bermanfaat, sehingga dapat diterapkan oleh khalayak banyak di dalam kehidupan sehari-hari.

c. Dituntut untuk mengabdi kepada masyarakat, yakni berupa keterlibatan langsung membina masyarakat guna peningkatan taraf kehidupan.

Dalam sebuah riset dijelaskan, profesi dosen tida sama dengan guru, hal ini terletak pada kedudukannya (Prokofyeva, et, al., 2019; Surasmi, et, al., 2019). Di mana 
seorang dosen dititik beratkan pada tiga kewajiban, yakni (UU No. 14 tahun 2005 Pasal $60)$ :

1. Pendidikan. Artinya, seorang dosen adalah seorang pelajar sekaligus pengajar. Sehingga seluruh kehidupannya didedikasikan untuk menimba ilmu dan mengamalkan ilmu (bertigas mencerdasakan kehidupan bangsa, termasuk dirinya)

2. Penelitian. Artinya seorang dosen adalah pemecah masalah. Maksudnya, proses belajar dan mengajarnya seorang dosen adalah sebagai upaya melahirkan karyakarya, sehingga memberikan kontribusi terhadap lahirnya efektivitas dan efisiensi di dalam ilmu pengetahuan dan pengamalannya (Indrawan, et, al., 2019).

3. Pengabdian. Artinya seroang dosen adalah sebagai pengamal atas ilmu dan pengembangan ilmunya. Ia membaur dengan masyarakat di dalam menyelesaiakn persoalan-persoalan hidup, baik bidang pendidikan, ekonomi, sosial, hukum, politik, dan sebagainya. Pada tahap ini, seorang dosen tidak lagi ditahap berpikir atau berargumentasi (teoritis), melainkan di tahap empiris (pelaksanaan) dengan sebuah misi membaktikan hidup untuk kebermanfaatan.

\section{METODE PENELITIAN}

Dasar pemikiran dari penelitian ini adalah induktif. Di mana penelitian dilakukan atas realitas pada suatu objek, dengan demikian sifat dari penelitian ini adalah khusus. Dengan kata lain, penelitian ini adalah upaya peneliti di dalam memahami realitas yang ada dengan menggali informasi pada objek penelitian secara mendasar, dengan tujuan mendapatkan informasi yang berguna di dalam mengemukakan suatu fenomena.

Secara teoritis, alasan menggunakan pendekatan kualitatif adalah karena sifatnya yang langsung berhubungan dengan sampel sumber data. Sehingga lebih memungkinkan memperoleh informasi yang lebih alamiah atau natural. Hal tersebut terjadi karena dalam prakteknya, pendekatan kualitatif mengedepankan teknik sosial, psikologi dan emosional, dengan demikian informan di dalam menyampaikan informasi dan atau data didasari keinginannya, maka ia akan mengemukakan semua informasi.

Dalam penelitian ini, populasi yang dimaksud adalah obyek yang dapat diukur dan menjelaskan fenomena yang tengah diamati, yakni data-data yang menunjukkan kinerja dosen, yakni:

1. Data pendidikan, yang diperoleh dari laman PDDIKTI 
2. Data kepangkatan, yang diperoleh dari Kepegawaian Unpam

3. Data sertifikasi dosen, yang diperoleh dari Kepegawaian Unpam

4. Data penelitian, yang diperoleh dari LPPM Unpam

5. Data publikasi karya ilmiah, yang diperoleh dari laman Sinta Ristek Dikti.

6. Data kegiatan PKM dan Haki, yang diperoleh dari LPPM Unpam.

Dengan informasi tersebut, maka sampel yang akan dijadikan sumber data adalah sampel dengan kriteria tersebut:

1. Data resmi yang dikeluarkan oleh lembaga-lembaga yang memiliki data tersebut di atas

2. Data yang menggambarkan kondisi riil kinerja dosen

3. Data yang relevan dengan fenomena yang diangkat

4. Data yang dapat diukur dan dianalisis

Adapun teknik sampel yang digunakan menggunakan teknik purposif, di mana sampel sumber data adalah sumber informasi yang telah memenuhi kriteria tersebut di atas. Alasan pemilihan teknik ini adalah, untuk mendekati pada suatu kinerja yang telah ditetapkan, baik berdasarkan Undang - Undang, Peraturan Pemerintah, maupun yang berlaku di Perguruan Tinggi tersebut.

Data yang terkumpul kemudian di analisis secara deskriptif, sehingga fenomena dapat diargumentasikan sesuai keadaan aslinya. Dengan demikian, penarikan kesimpulan bersifat situasional, akurat, dan berimbang. Hal tersebut dapat membantu objek penelitian mengidentifikasi solusi permasalahan secara tepat (operasional).

\section{HASIL PENELITIAN}

Kontribusi dosen dalam bidang pendidikan dapat dilihat pada indikator linearitas pendidikan dengan program studi, kepangkatan, dan sertifikasi dosen, dengan penjelasan sebagai berikut:

1. Kontribusi kinerja dosen dalam bidang pendidikan sub indikator linearitas menunjukkan kategori rendah. Hal ini dapat dilihat pada kelompok dosen dengan lulusan S2 sebanyak 73\% yang linear dengan program studi, sedangkan dosen dengan lulusan S3 sebanyak 2\%. Dari data ini, secara nyata kontribusi dosen sebesar 1 poin terhadap akreditasi perguruan tinggi. Fakta ini menegaskan, bahwa perguruan tinggi kekurangan tenaga pengajar yang memiliki tingkat linearitas 
pendidikan dengan program studi, sehingga dampaknya terhadap akreditasi kurang baik.

2. Begitupun pada indikator kepangkatan, senyatanya dosen dengan kepangkatan lektor kepalasa terbilang nihil (jauh di bawah 40\%). Di mana persentasenya masih di bawah $1 \%$. Tentu keadaan ini secara signifikan berdampak buruk terhadap akreditasi perguruan tinggi. Selain itu, fakta ini menegaskan, bahwa perguruan tinggi sangat kekurangan dosen dengan kepangkatan lektor kepala.

3. Lebih lanjut, rendahnya kontribusi dosen dalam bidang pendidikan sub indikator sertifikasi sebanyak $11 \%$, di bawah standar akreditasi $40 \%$. Kenyataan ini secara agregat memberikan poin akreditasi sebesar 1.

4. Uraian di atas mendeskripsikan, bahwa kinerja dosen dalam bidang pendidikan berdasarkan perspektif akreditasi tergolong rendah, yakni hanya menyumbangkan skor sebesar 1.

Kontribusi dosen dalam bidang penelitian dapat dilihat pada beberapa indikator, di antaranya:

1. Berdasarkan data yang ada (LPPM Universitas) belum ada satu pun penelitian dosen yang didanai oleh lembaga asing.

2. Berdasarkan data Sinta, diketahui jumlah jurnal terindeks internasional bereputasi sebanyak 165 atau $7.5 \%$ dari jumlah dosen.

3. Berdasarkan data yang ada (LPPM Universitas) sebanyak 200 HKI dari jurnal ilmiah.

4. Analisis di atas menyimpulkan, bahwa kontribusi dosen dalam bidang penelitian tergolong cukup, dengan skor 2 . Hal ini menegaskan, bahwa peran dosen dalam kegiatan penelitian masih jauh dari kebutuhan akreditasi, sehingga kontribusinya belum signifikan. Maka dari pada itu, kiranya institusi dapat membuat kebijakan atau stimulus guna memotivasi para dosen dalam meningkatkan kinerjanya dalam bidang penelitian.

Kontribusi dosen dalam bidang pengabdian kepada masyarakat dapat dilihat pada beberapa indikator, di antaranya:

1. Data LPPM menunjukkan bahwa tingkat pelaksanaan PKM tergolong cukup baik. Hal ini dapat dilihat dari jumlah kegiatan pada 3 tahun terakhir yang cukup signifikan, dalam setiap tahunnya tercatat sebanyak 440 kegiatan PKM yang 
dilakukan oleh dosen secara berkelompok. Keberhasilan ini terjadi karena secara sistemik telah dibuat aturan di mana seluruh dosen diwajibkan melakukan kegiatan PKM. Dari kinerja ini diperoleh poin akreditasi sebesar 2.

2. Namun, kekurangan dari PKM ini terletak pada luaran dari hasil kegiatan PKM dalam bentuk jurnal. Tercatat dari 440 kegiatan PKM hanya 50\% nya yang membuat jurnal. Tentu ini memberikan kontribusi poin yang rendah terhadap akreditasi lembaga (sebesar 1)

3. Selain itu, kekurangan pada kinerja PKM ini juga terletak pada HKI. Hal ini tercatat kurang dari 100 kegiatan PKM yang memiliki hak kekayaan intelektual.

4. Berdasarkan ketiga data di atas, maka secara agregat kontribusi kinerja dosen terhadap perguruan tinggi sebesar 2 poin.

\section{KESIMPULAN}

Berdasarkan hasil dan pembahasan di atas, maka dapat dikemukakan temuan dan rekomendasi penelitian sebagai berikut:

1. Kinerja pendidikan

Pada bidang pendidikan, kinerja dosen berkontribusi terhadap akreditasi lembaga sebesar 37,5\% atau memberikan sumbangan skor akreditasi sebesar 1 (rata-rata), masuk pada kategori rendah. Rendahnya capaian tersebut teridentifikasi adanya masalah-masalah sebagai berikut (tersusun berdasarkan skala besar dampaknya/masalahnya):

a. Dosen yang berpangkat lektor kepala tergolong sangat sedikit (di bandingkan dengan jumlah dosen tetap)

b. Linearitas pendidikan dosen pada jenjang S3 terbilang sangat sedikit (di bandingkan dengan jumlah dosen tetap)

c. Jumlah dosen yang memiliki sertifikasi masih sedikit (di bawah 40\%)

d. Linearitas pendidikan dosen pada jenjang S2 masih di bawah $90 \%$

Dengan demikian berarti:

a. Perguruan tinggi kekurangan dosen yang berpangkat lektor kepala

b. Perguruan tinggi kekurangan dosen yang bergelar S3

c. Perguruan tinggi kekurangan dosen bersertifikasi 
d. Perguruan tinggi perlu meningkatkan linearitas pendidikan dosen, khususnya pada jenjang S2.

2. Kinerja penelitian

Pada bidang penelitian, kinerja dosen berkontribusi terhadap akreditasi lembaga sebesar 50\% atau memberikan sumbangan skor akreditasi sebesar 2 (rata-rata), masuk pada kategori cukup. Belum maksimalnya capaian tersebut teridentifikasi adanya masalah-masalah sebagai berikut (tersusun berdasarkan skala besar dampaknya/masalahnya):

a. Jumlah publikasi pada jurnal ilmiah internasional dan nasional bereputasi sangat sedikit.

b. Tidak ada penelitian yang didanai oleh lembaga internasional, dan penelitian yang didanai dari dalam negeri sangat sedikit jumlahnya.

c. Jumlah karya ilmiah yang memiliki HAKI dan atau diakui baik secara nasional maupun internasional sangat sedikit.

\section{Kinerja PKM}

Pada bidang pengabdian, kinerja dosen berkontribusi terhadap akreditasi lembaga sebesar 50\% atau memberikan sumbangan skor akreditasi sebesar 2 (rata-rata), masuk pada kategori cukup. Belum maksimalnya capaian tersebut teridentifikasi adanya masalah-masalah sebagai berikut (tersusun berdasarkan skala besar dampaknya/masalahnya):

a. Tidak ada luaran hasil dari kegiatan PKM yang terpublikasi pada jurnal ilmiah internasional dan nasional bereputasi.

b. Tidak ada kegiatan PKM mendapatkan pendanaan dari lembaga nasional maupun internasional.

c. Tidak ada luaran hasil dari kegiatan PKM yang memiliki HAKI atau mendapatkan penghargaan pada tingkat nasional maupun internasional.

\section{DAFTAR PUSTAKA}

Abramovskikh, N. V., Tolmacheva, V. V., Vasyagina, N. N., \& Shempeieva, N. I. (2019). Research and methodological support of professional activity quality of a lecturer. In The European Proceedings of Social \& Behavioural Sciences EpSBS (pp. 10-17).

Aisyah, N., Ambarita, B., \& Sibuea, A. M. (2019). Significance between Organizational Culture and Lecturer Performance of Private Universities in Medan. Budapest 
International Research and Critics Institute (BIRCI-Journal): Humanities and Social Sciences, 2(2), 75-88.

Hazriyanto, H., Afridola, S., \& Ibrahim, B. (2019). Assessment Of Lecturer Performance On Social Competencies At Ibn Sina Islamic High School. Eksis: Jurnal Riset Ekonomi dan Bisnis, 14(1), 13-26.

Indrawan, M. I., Alamsyah, B., Fatmawati, I., Indira, S. S., Nita, S., Siregar, M., ... \& Tarigan, A. S. P. (2019, March). UNPAB Lecturer Assessment and Performance Model based on Indonesia Science and Technology Index. In Journal of Physics: Conference Series (Vol. 1175, No. 1, p. 012268). IOP Publishing.

Pachler, D., Kuonath, A., \& Frey, D. (2019). How transformational lecturers promote students' engagement, creativity, and task performance: The mediating role of trust in lecturer and self-efficacy. Learning and Individual Differences, 69, 162172.

Prokofyeva, N., Zavjalova, O., \& Boltunova, V. (2019, May). Feedback Method in Lecturer-Student Interaction. In Proceedings of the International Scientific Conference. Volume I (Vol. 442, p. 448).

Putri, W., Kesaulya, F. A., \& Pratama, Y. D. (2019). Student Behavior Intention: An Analysis of Culture, Lecturer Performance, and Academic Services Quality. Journal of Accounting and Strategic Finance, 2(1), 34-47.

Salbiah, S., Nuraini, F., \& Rosmaniar, A. (2019). Motivation And Its Effect On Women's Lecturer Performance In University of Muhammadiyah Surabaya. International Journal of Economics and Management Studies, 6(9), 22-33.

Sofyani, H., \& Nazaruddin, I. (2019). THE EFFECT OF IMPLEMENTATION OF LECTURE PERFORMANCE MEASUREMENT SYSTEM AND THE ROLE CLARITY OF LECTURER PERFORMANCE: A STUDY OF TESTING MEDIATION EFFECT. Jurnal Reviu Akuntansi dan Keuangan, 9(1), 34-45.

Suherman, A., Mulyasana, D., \& Mulyasa, E. (2019). Faktor-Faktor Determinan Terhadap Kinerja Dosen Dalam Meningkatkan Mutu Layanan Akademik Pendidikan Tinggi. Kajian Manajemen Pendidikan, 1(2), 1-10.

Surasmi, I. A., Azis, I. S. A., \& Artawan, I. M. (2019). Effect of Individual Characteristics, Work Characteristics and Organizational Characteristics on the Permanent Lecturer Performance at Warmadewa University. International Journal of Contemporary Research and Review, 10(12), 21693-21699.

Thach, P. N., Phuong, B. H., Dung, C. C., Van, L. H., \& Diep, P. T. H. (2019). A Dynamic Fuzzy Multiple Criteria Decision-Making Approach for Lecturer Performance Evaluation. Journal of Management Information and Decision Sciences, 22(3), 250-261.

Yulianti, P. (2020). EVALUASI PENILAIAN KINERJA DOSEN DIDASARKAN PADA KOMPETENSI (STUDI KASUS PADA DOSEN FEB UNIVERSITAS DHARMA ANDALAS PADANG). Menara Ilmu, 14(2). 